\title{
Establishment of Shari'Ah Supervisory Committee in Hospital: An Analysis from Perspective of Public Interest
}

\author{
Muhammad Adib Samsudin ${ }^{1}$, Mohammad Zaini Yahaya ${ }^{1}$, Mohd Izhar Ariff Mohd Kashim ${ }^{1}$, Hayatullah \\ Lalulddin $^{2}$, Ahmad Munawar Ismail ${ }^{1}$, Rozida Mohd Khalid ${ }^{3}$, Irwan Mohd Sobri ${ }^{4} \&$ Syed Azhar bin Syed \\ Sulaiman $^{5}$ \\ ${ }^{1}$ Department of Shari'ah, Faculty of Islamic Studies, National University of Malaysia, Malaysia \\ ${ }^{2}$ Department of Economics, Faculty of Economics and Management Sciences International Islamic University \\ Malaysia, Malaysia \\ ${ }^{3}$ Centre for the Study of Science of chemistry and Food Technology, Faculty of Science and Technology UKM, \\ Malaysia \\ ${ }^{4}$ Faculty of Shari'ah and Laws University of Islamic Sciences Malaysia, Malaysia \\ ${ }^{5}$ Centre for Study of Science of Pharmacy, University of Science Malaysia, Malaysia \\ Correspondence: Muhammad Adib Samsudin, Department of Shari'ah, Faculty of Islamic Studies, National \\ University of Malaysia, Malaysia. E-mail: azhari926@gmail.com
}

Received: June 20, 2014 Accepted: November 28, 2014 Online Published: January 14, 2015

doi:10.5539/ass.v11n4p43 URL: http://dx.doi.org/10.5539/ass.v11n4p43

\begin{abstract}
Although hospitals' management currently observe all general rules set by the government nevertheless, there are certain short comings on the part of management, as it lacks comliance with the requirement of Shari'ah in respects of selection of medicine, the relations between the patients and the doctors of differnt gender, and the lack of the knowledge of Shari'ah's ruling pertainning to the treatment by staffs and the patients in the hospital. These three aspects should be given serious attention and be handled wisely so as to maintain and preserve Malaysia's status as a majority Muslim country. As regards the selection of the medicine or pharmaceutical material, there is a lingerring doubt concerning the status of the medicine given to patient whether it is halal (permissible) or haram (impermissible). For instance, the medicine for allergy Red Tab Claritin and Ultratab Allergy Tablet Benadryl contain materials that originate from pig and cow. Meanwhile, there are numerous complaints from female patients especially, during labour hours in the delivery hall handaled by male doctors. Some of them don't feel easy and confortable with the birth procedure being conducted by male doctors. Therefore, to cater for the need of the Muslim community constituting the majority of Malaysia's population, it is appropriate to establish a committee tasked with making sure that the hospitals operate in accordance with the requirement of the Shari'ah. Therefore, this paper attempts to explore the concept of maslahah from the perspective of Islamic law and its instrumental role in the establishment of Shari'ah Supervisory Committee in hospitals. This paper uses both document analysis and interview methods. The findings of this study show that maslahah can play an instrumental role in establishing Shari'ah Supervisory Committee in the hospital from the aspects of enhancement of general public interest of necessity category.
\end{abstract}

Keywords: hospital, management, Muslim community, establishment

\section{Introduction}

Islam as a comprehensive religion protects and enhances the interest of the humanity as a whole. The fact that the prophet Muhammad PBUH was sent as a mercy to humanity presents a solid testimony to this signification. For, mercy generally includes, among other things, protection and safeguarding people's interest. The Shari'ah aims at safeguarding people's interest in this world and in the next. God instituted the Shari'ah for the benefit of mankind both in this word and the next. He has in fact singled out maslahah as the only objective of the Shari'ah.Therefore, this paper attempts to provide a brief account of the explanation of the concept of maslahah in the classic and contemporary works of Islamic jurisprudence. It also shades some light on maslahah instrumental role for justification and establishment of Shari'ah Supervisory Committee in hospitals. 


\section{Definition of Maslahah}

The word maslahah etymologically signifies two meanings ('Abdul Wadud, 1987):

a) Infinitive noun which means al-salah (good) (al-Marbawi, 1350H) in the same manner as the word al-manf'ah means al-naf' (benefit). Al-salah means something being in its perfect or complete condition, as can be expected. For example, the perfectness of a pen is manifest from its effective use for writing. In the same manner, the perfectness of a sword lays in the attribute of its sharpness.

b) An action of such a nature that generates benefit and removes harm. Maslahah's signification in this sense is a metaphorical generalization where the cause leading to a consequence is meant by itself and not the consequence. In other words, generalization of the word maslahah represents the consequence of an action which constitutes its cause. For example. Considering business as a form of a maslahah, will mean its being a cause for obtaining material benefit. In general, the definition of maslahah as understood by jurists can be articulated as the benefit determined by the Law Giver the Almighty to His servants by preservation of religion, life, intellect, property and the lineage.(Al-Buti, 2000)

\section{Classification of Maslahah}

Considering maslahah from the aspects of its strength, comprehension and the acknowledgement of Shari'ah ('Abd al-Wdud, 1987) can be divided into a few divisions as follows.

\subsection{The Aspect of Strength and Weakness}

From this aspect it can be divided into three categories comprising:

a) Al-daruriyyah. It is a type of maslahah which is related to the basic needs of human being in this world and the Hereafter. Its absence leads to the disruption of human life and brings about regret in the hereafter. (Al-Shatibi, n.d.) For instance, the obligation of performing the five pillars of Islam is a form of necessity category without which the establishment of religion hence, the smooth running of life cannot be expected.

b) Al-hajiyyah. It is a type of maslahah which is needed for convenience and ease in life. It removes difficulty and hardship from human life and yet its absence does not lead to the disruption of human life. Its non-existence would only cause a little bit of hardship. (Al-Shatibi, n. d.) For example, the concession given to a person to combine and shorten prayers during his journey is meant to remove the hardship by reducing the amount of prayer while travelling.

c) Al-tahsiniyyah. It refers to a type of maslahah which is concerned with good behavior and etiquette and requires the avoidance of things disliked by sound reason. Its non-existence would not have any significant effects on the human life as the two earlier categories. (Al-Shatibi, n. d.) Its example is the wearing of nice clothes and use of fragrance/ perfume when performing congregational prayer in Mosque.

\subsection{The Aspect of Its Scope and Limitation}

In addition to the above aspect, maslahah can also be divided into three other categories from the aspect of its scope and limitation. This categories comprise; maslahah ammah, (general benefit) maslahah aghlabiyyah (major benefit) and maslahah khassah (specific benefit). (Hassan, 1971) This division plays an important role as a guide for the prioritization in case of conflict between masalih (plural of maslahah) in the process of derivation of ruling. However, this division in terms of its source can be further classified into three following categories (Al-Buti, 2000)

a) Maslahah mu'tabarah, a kind of maslahah which is supported by a textual source or consensus. ('Abd al-Wadud, 1987) In other words, this type of maslahah is acknowledged by the law either through textual source or consensus. For example, the legality of the hudud ( fix punishment) as a punishment for the crime of theft is meant for the purpose of preservation of the public interest pertaining to the property, for which a specific text in the Holy Qur'an is provided as follow:

"A man and woman who commit the crime of theft amputate their hand as the punishment for the crime they have committed and as retribution from Allah SWT the most powerful and wise." (al-Qur'an, 5:38)

In the above verse the Law Giver has prescribed the exact ruling for the crime of theft which is the amputation of the hand. The cause for which is the attribute of theft itself. Amputation therefore, as a punishment for the crime of theft serves as a deterrent for those with the intention of theft hence, leading to the preservation of property as an element of maqasid al-shari'ah, (the objective of the law) a fact which no sound and rational mind would reject. 
b) Maslahah mulghat, is a kind of maslahah which is rejected by a specific textual source ("Abd al-Wadud, 1987) an example for this kind of maslahah is the obligation of fasting two months consecutively as the starting point in the order of compensation for zihar before attempting to set free a slave. This situation is specifically meant for those who could easily do so in comparison to fasting. Even though this can be seen as much more contributing to the public interest from rational point of view. However, it is not considered so due to its conflict with the following textual source:

"Those who make the oath of zihar with their wives than tend to return back to them. They should set free a slave before they touch their wives, so Allah advise you and Allah knows what you do. Those who could not afford to do so they should fast for two months consecutively before attempting to touch their wives even if they could not afford to do so they should feed sixty poor."

From the above verse it is clear that Allah SWT has determined the order of the zihar compensation which starts with freeing of a slave and ends with the provision of food for sixty destitutes. This nullifies the specification of fasting as the starting point in the order of zihar's compensation for, fasting can only be opted to as the last resort when setting free a slave is beyond one's means.

c) Malahah mursalah is a kind of maslahah which is neither supported nor rejected by any specific evidence. Nevertheless, it is approved tacitly by the Law. For example, the action of the first Caliph Abu Bakar MABPH to compile the Qur'an which was scattered and put them together in one single book is based on the concept of the maslahah mursalah. Even though the decision taken by Abu Bakar MABPH has no specific textual source for its support yet it was a rational and suitable decision for the preservation and protection of the Qur'an.

\section{Malahah's Role in Shari'ah Supervisory Committee in Hospitals}

Islam is a complete religion and this is supported by the Qur'anic verse:

"Today I have perfected your religion for you and completed my bounty on you..."

The above verse shows that Islam as a complete religion includes all aspects of human being life be it political, economic and social. One of the features of the perfection of Islam is that it provides a guideline pertaining to the medicine and the treatment of patients. However, all hospital having their own rules and regulations including those under the government, to which they strictly adhere, this does not necessarily means they are fully Shari'ah compliant in respect of their operation and provision of appropriate medicine for the patients. In other words, the operation of hospitals in certain respects does not fulfill the requirements of Shari'ah. The aspects lacking compliance with the requirement of Shari'ah relate to the selection of medicine, the relation between doctors and the patients of a different gender and the unawareness of the staffs and patients of the relevant Shari'ah rulings.

\section{Selection of Medication}

From the pharmaceutical aspect or selection of medicine, there is a lingering doubt as regard to the nature of the medicine given to the patients whether it is permissible or impermissible. For example, the medicine for allergy called Red Tab Claritin and Allergy Ultra tab Tablet Benadryl is made from substance which component elements come from pig and cow. The former being forbidden by Islamic law while the latter being permissible as long as it is slaughter is conducted in according to process prescribed by Shari'ah. (Syed Azhar, 2013) The same line of argument goes to the Clotimazol which source primarily comes from pig (Syed Azhar, 2013) according to professor Dr. Syed Azhar Syed Sulaiman (2013) who is currently holding deanship post in the faculty of pharmacy University Science of Malaysia, the medicine that the hospitals provide for the patient come in various forms and therefore, is not limited to one form or consumed orally only.. It rather involves variety of dos. The vaccine which is often used for different kinds of disease has been made from enzyme or protein which is originated from pig. Another commonly used form of medicine in the hospitals is the injection with variety of its forms primarily insulin. Its process of manufacturing involves the elements which come from non-halal (impermissible) source. He further argues saying that the material which are used for making the medicine may also come from the sources which are definitely non- halal or at least doubtful in nature. Despite all these presumptions and perception they are widely used in the hospitals. He holds that even though the active material of a medicine may be halal, (permissible) but its fastener material, carrier material, or solvent or lubricants may not be made from permissible material.

Consequently, to establish a committee with its main focus and stress on the halal, became the need of the day for the Muslim society. This is to ensure that the medicines used in the hospitals are of the halal origin and the operation of the hospitals and the attitudes of the medical staff and treatment of patients are in line with Shari'ah principles and do not violate the Islamic code of ethics. The measures taken in this respect for the purpose of the realization of compliance with Shari'ah in these three aspects will propel Malaysia to greater height hence, 
positioning its health system in a better position and enhancing halal products service in the field of medicine and health products. MS2424 which is produced in this country has the potential to become a catalyst for the production of halal pharmaceutical products. For, it has significantly, attracted Muslim community and other religious community which are extremely concerned the cleanliness and purity in making of medicine. Therefore, formation of a committee which is tasked this aspect of social life represents maslahah 'ammah, general public interest of Muslim society which can be classified under the category of approved maslahah. For, the Muslims are required to commit things that are permissible and avoid the impermissible ones. Allah the Almighty says:

"Say oh Muhammad! Who dare to prohibit ornament that Allah has brought forth for His servants and good things for living"

In the above verse Allah SWT reprimand the ignorant people due to prohibiting permissible things whether in the form of ornaments of food. The reason that Allah SWT reprimanded them was due to their attempt of changing the status of permitted things to that prohibited ones thus, their perception and commission of such act is considered as a sin. Therefore, whenever, something is declared as prohibited it is forbidden to commit it, whereas, if something is declared as permitted it must be done and should not be abandoned. This is confirmed in the saying of the prophet PBUH as follow:

"Permitted things as well as the prohibited things are made clear"

\section{Relation between Doctors and Patients}

Another aspect that requires serious consideration by hospital management is the relation between the patients and the doctors especially of different gender. This aspect should be viewed in the light of Islamic guidelines. If it violates the Islamic code of ethics it should be rectified to fulfil the requirement Shari'ah hence, achieving the required level of compliance with Shari'ah. The urgency of need for such consideration is obvious as there are many complaints made by female patients especially during their labor hours in the delivery hall. For, some of them do not feel comfortable when the procedure of delivery is handled by male doctors (Anon, 2011). The severity of this phenomenon is clear from the statement made by a participant in a forum on the website, stating that a male trainer doctor was chosen by the specialist doctor to put the pill for urination for the female patient while in the process of delivery (2002). This disgracing act should not happen for the job can be delegated to a female trainer doctor or the nurses to handle. Muslim scholars have made it necessary that the entire process of the child delivery be conducted and handled by female doctors. Even if patient is non-Muslim, except in the cases of emergency. ('Atiyyah Saqar, 2002) Although, the doctors are bound by medical ethics under the Medical Malaysian Council (MMC) the enforcement of rulings pertaining to halal and haram is not within their discretion. Therefore, it is imperative to establish a Shari'ah Supervisory Committee in hospitals to make sure that the commandments of Allah SWT in this regard are fully abided by. Thus, considering the urgency of need for the establishment of such committee it can be viewed as form of maslahah which cannot be denied. It is in this sense that the instrumentality of the role of maslahah in establishment of Shari'ah Supervisory Committee can be visualized

\section{Medical Staff's Knowledge of Relevant Islamic Ruling}

Spiritual nourishment of the medical staff and the patients and their knowledge of how to perform worship must also be given an appropriate consideration. The necessity for such consideration was identified in a report provided by the Islamic Affairs Assistant at Hospital Serdang (Dewiyana SAPARUDDIN, 2012), during conducting courses related to the worship of patients and staff under the name "Worship of Patients: Theory and Practice " and " a workshop under the theme "Worship Friendly Hospital " 8 times in a year. Similarly, a another course was organized and conducted under the title "Provide Guidance and Counsel to Staff About Patients' Worship in Hospital" 8 times in a year, as well, with 500 participants attending it. All these courses were conducted by the Missionary Unit of Serdang and some other selected hospitals such as Selayang, Sg. Buloh and Klang Tengku Ampuan Rahimah hospitals. This indicates the significance of religious program and its overwhelming positive effect on the mind and spirit of medical staffs and patients. It is therefore, highly recommendable to introduce the Shari'ah Supervisory Committee in all Hospital throughout Malaysia.

\section{Conclusion}

The attainment of a real maslahah can only be realized through submission to the commandments of Allah SWT as is clear from the following verse:

"And if the people of the townships had believed and kept from evil, surely we should have opened for them blessings from the sky and from the earth. But (unto every messenger) they gave the lie, and so we seized them on account of what they used to earn" (Qur'an, 7:96) 
From this verse it is clear that the benefit and interest of humanity can only be attained through strong belief and piety. It can be manifested through the implementation of every single commandment of Allah SWT and the avoidance of His prohibitions. In other words, the implementation of Islamic Law represents the real maslahah from all its dimensions, essence, scope and admissibility. Thus the establishment of the Shari'ah supervisory committee in the hospitals with the main objective of ensuring Shari'ah compliance is a maslahah which on no account should be neglected.

\section{References}

'Atiyyah Saqr. (2002). Fatawa wa Ahkam li al-Mar'ah al-Muslimah. Al-Qahirah: Maktabah Wahbah.

Al-Butiyy, M. S. R. (1421H/2000). Dawabit al-maslahah fi al-sharicah al-Islamiyyah. Cet. ke-6. Beirut: Mu'assasat al-Risalah.

al-Marbawi, M. I. (1350H). Kamus al-Marbawi. al-Qahirah: al-Halabi.

Al-Quran.

Al-Shatibiyy, I. B. M. (T.th). al-Muwafaqat fi usul al-sharic ${ }^{c}$ ah sunt. ${ }^{\mathrm{c}}$ Abdullah Darraz. 4 juz. Beirut : Dar al-Kutub al-'Ilmiyyah.

al-Wadud, R. ${ }^{c}$ A. (1407H/1987). al-Taclil bi al-maslahah ${ }^{c}$ inda al-usuliyyin. Sayyidah Zainab: Dar al-Huda li al-Taba ${ }^{\mathrm{c}} \mathrm{ah}$.

Anon. (2011). Retrieved May 8, 2013, from http://mindsay.11.forumer.com/viewtopic.php?t=933

Hassan, H. H. (1971). Nazariyyat al-maslahah fi al-fiqh al-Islamiyy. Mesir: Dar al-Nahdah al- ${ }^{\mathrm{c} A r a b i y y a h . ~}$

Kathir, I. (1917H/1996). Tafsir al-Qur'an al- ${ }^{c} a z i m$ sunt. Taha ${ }^{c} A b d$ al-Ra'uf Sa ${ }^{c} d .3$ jil. Maktabat al-Iman, al-Mansurah, juz 2.

Qutb, S. (1407H/1987). Fi zilal al-Quran. 6 jil. Cet. ke-13. al-Qahirah : Dar al-Shuruq.

Shalabiyy, M. M. (T.th). Tac lil al-ahkam. Beirut : Dar al-Nahdah al- ${ }^{\mathrm{c} A r a b i y y a h . ~}$

Sulaiman, S. A. S. (2013). Pemilihan ubat di hospital kerajaan. Temu bual: 24 Jun 2013.

\section{Copyrights}

Copyright for this article is retained by the author(s), with first publication rights granted to the journal.

This is an open-access article distributed under the terms and conditions of the Creative Commons Attribution license (http://creativecommons.org/licenses/by/3.0/). 